\title{
Penguatan Pendidikan Karakter Siswa SD Melalui Pembiasaan pada Pembelajaran Jarak Jauh
}

\author{
Kevinna Risqy Agma Widayat*, Sa'dun Akbar, Imam Nawawi \\ Universitas Negeri Malang, Jl. Semarang No. 5 Malang, Jawa Timur, Indonesia \\ *Penulis korespondensi, Surel: kevinna.risqy.1701516@students.um.ac.id
}

Paper received: 7-6-2021; revised: 21-6-2021; accepted: 28-6-2021

\begin{abstract}
This research focuses on PPK (Strengthening Character Education) activities through habituation in distance learning and to interpreting the role of habituation in the context of PPK (Strengthening Character Education) in distance learning at SDN Kotalama 1 Kota Malang. In order for the results of this study to be more accurate, the researchers used mixed methods. The approach used is a quantitative approach and a qualitative approach. The results of this study are the role of PPK (Strengthening Character Education) activities through habituation in distance learning that is not maximal in seeing the attitudes and behavior of students directly. The role of PPK through habituation in distance learning, namely as a controller and introduction to various daily activities at home for students. The implementation of PPK through habituation is carried out every morning before learning activities begin.
\end{abstract}

Keywords: strengthening character education; habits; attitudes and behaviors of students

\begin{abstract}
Abstrak
Penelitian ini berfokus pada kegiatan PPK (Penguatan Pendidikan Karakter) melalui pembiasaan pada pembelajaran jarak jauh dan bertujuan untuk memaknai peranan pembiasaan dalam konteks PPK (Penguatan Pendidikan Karakter) pada pembelajaran jarak jauh di SDN Kotalama 1 Kota Malang. Agar hasil penelitian ini menjadi lebih akurat maka peneliti menggunakan metode penelitian campuran atau mixed methods. Pendekatan yang digunakan yaitu pendekatan kuantitatif dan pendekatan kualitatif. Hasil penelitian ini yaitu peranan kegiatan PPK (Penguatan Pendidikan Karakter) melalui pembiasaan pada pembelajaran jarak jauh kurang maksimal dalam melihat sikap dan perilaku peserta didik secara langsung. Peranan PPK melalui pembiasaan pada pembelajaran jarak jauh yaitu sebagai pengontrol dan pengenalan berbagai kegiatan sehari-hari di rumah bagi peserta didik. Pelaksanaan PPK melalui pembiasaan dilaksanakan setiap pagi sebelum kegiatan pembelajaran dimulai, guru memberikan kegiatan melalui grup whatsapp dan peserta didik mengirimkan bukti berupa foto atau video saat melaksanakan kegiatan PPK kepada guru.
\end{abstract}

Kata kunci: penguatan pendidikan karakter; pembiasaan; sikap dan perilaku peserta didik

\section{Pendahuluan}

Globalisasi yang terjadi di dunia membuat budaya barat yang negatif masuk ke Indonesia, sehingga mempengaruhi budaya timur yang dimiliki oleh Indonesia. Salah satu akibat atau dampak yang serius bagi masyarakat yaitu hilangnya budaya sopan santun, tata krama, dan norma-norma yang ada di lingkungan masyarakat. Fenomena dehumanisasi dan demoralisasi yang muncul di lingkungan masyarakat merupakan suatu tanda bahwa sudah mulai pudar norma-norma ketimuran yang ada di masyarakat (Affan \& Maksum, 2016).

Percepatan fenomena dehumanisasi dan demoralisasi serta perkembangan informasi dan komunikasi menjadikan begitu banyak manusia terasing dari Tuhannya, sesama manusia, lingkungan hidupnya, bangsa dan negaranya, dan dari dirinya sendiri. Bukti yang dapat dilihat yaitu kurang peduli terhadap sesama, kurang rasa saling menghargai, mementingkan 
kepentingan pribadi dibandingkan golongan, hingga pergaulan yang merusak diri sendiri (Akbar, 2016).

Seiring berjalannya waktu peserta didik akan terjun langsung dan hidup di lingkungan masyarakat yang mengalami fenomena dehumanisasi dan demoralisasi. Tentu upaya yang komprehensif harus dilakukan oleh pemerintah, salah satu upaya yang dilakukan melalui pendidikan. Menurut Undang-undang Nomor 20 Tahun 2003 menyatakan bahwa pendidikan dapat mengembangkan kemampuan dan membentuk watak (karakter) serta peradaban bangsa yang bermartabat dalam rangka mencerdaskan kehidupan bangsa, maka pendidikan nasional bertujuan untuk mengembangkan potensi peserta didik agar menjadi manusia yang beriman dan bertaqwa kepada Tuhan Yang Maha Esa, berakhlak mulia, sehat, berilmu, cakap, kreatif, mandiri dan menjadi warga negara yang demokratis serta bertanggung jawab.

Adanya undang-undang Nomor 20 tahun 2003 memperkuat bahwa pendidikan bukan hanya sekedar menyampaikan ilmu pengetahuan saja, namun pendidikan sangat penting untuk menunjang pembentukan karakter. Pendidikan karakter merupakan kebiasaan yang terjadi untuk membentuk sifat anak yang terpupuk sejak kecil kemudian akan diterapkan dalam kehidupan sehari-hari yang memiliki tujuan mengembangkan kemampuan peserta didik untuk memberi keputusan baik-buruk, memelihara apa yang baik, dan mewujudkan kebaikan itu dalam kehidupan sehari-hari dengan sepenuh hati (Fitri, 2021; Samani, M \& Hariyanto, 2013).

Penguatan kembali dan revitalisasi pendidikan karakter perlu dilakukan guna menanggulangi dehumanisasi dan demoralisasi (Akbar, 2011). Berbagai upaya dilakukan oleh pemerintah seperti dalam Kurikulum KTSP (Kurikulum Tingkat Satuan Pendidikan) menjadikan pelajaran PKn sebagai pelajaran yang mengajarkan nilai dan moral, pelajaran PKn memiliki misi pendidikan nilai dan moral (Nawawi, 2012). Pada kurikulum 2013 pemerintah membuat program PPK (Penguatan Pendidikan Karakter).

Permendikbud Nomor 20 Tahun 2018 tentang penguatan pendidikan karakter pada satuan pendidikan formal, penguatan pendidikan karakter atau yang disingkat dengan PPK adalah gerakan pendidikan di bawah tanggung jawab satuan pendidikan untuk memperkuat karakter peserta didik melalui harmonisasi olah hati, olah rasa, olah pikir, dan olah raga dengan pelibatan dan kerja sama antara satuan pendidikan, keluarga, dan masyarakat sebagai bagian dari Gerakan Nasional Revolusi Mental (GNRM). PPK (Penguatan Pendidikan Karakter) memiliki lima nilai utama karakter yaitu religius, nasionalis, mandiri, gotong royong, dan integritas.

Kegiatan PPK (Penguatan Pendidikan Karakter) dapat diintegrasikan di berbagai kegiatan pendidikan yaitu intrakurikuler, kokurikuler, dan ekstrakurikuler. Sekolah diberi kebebasan untuk mengembangkan pelaksanaan program kegiatan PPK (Penguatan Pendidikan Karakter). Pelaksanaan PPK (Penguatan Pendidikan Karakter) dibagi menjadi tiga basis yaitu (1) penguatan pendidikan karakter berbasis kelas, (2) penguatan pendidikan karakter berbasis budaya sekolah, dan (3) penguatan pendidikan karakter berbasis masyarakat (Tim PPK Kemendikbud, 2017).

Pelaksanaan kegiatan PPK (Penguatan Pendidikan Karakter) di setiap Lembaga berbeda. Contohnya di SDN Kotalama 1 Kota Malang yang memiliki program pembiasaan dalam konteks PPK (Penguatan Pendidikan Karakter). Program PPK (Penguatan Pendidikan Karakter) 
melalui pembiasaan dilaksanakan setiap pagi sebelum pembelajaran dimulai. Guru memberikan berbagai kegiatan PPK (Penguatan Pendidikan Karakter) melalui pembiasaan dengan menyesuaikan keadaan. Kegiatan yang diberikan sesuai dengan jadwal yang telah disusun oleh tim kurikulum. Jadwal setiap tingkatan kelas berbeda. Contohnya di kelas VI hari Senin adalah pelaksanaan karakter nasionalis, hari Selasa adalah karakter integritas, hari Rabu adalah karakter kemandirian, hari Kamis adalah karakter gotong royong, hari Jum'at adalah karakter religius.

Selama pandemi Covid-19 ini program PPK (Penguatan Pendidikan Karakter) dilaksanakan melalui grup whatsapp. berbeda dengan pelaksanaan kegiatan PPK (Penguatan Pendidikan Karakter) melalui pembiasaan sebelum pandemi kegiatan dilaksanakan di kelas dan interaksi dilakukan bersama antar peserta didik. Sedangkan selama pandemi Covid-19 kegiatan PPK (Penguatan Pendidikan Karakter) dilaksanakan di rumah dan interaksi dilakukan bersama anggota keluarga di rumah.

Tidak semua sekolah memiliki program seperti yang dilaksanakan di SDN Kotalama 1 Kota Malang ini. Oleh karena itu, peneliti akan melakukan riset mengenai peranan PPK (Penguatan Pendidikan Karakter) melalui pembiasaan yang bertujuan untuk memaknai peranan kegiatan PPK (Penguatan Pendidikan Karakter) melalui pembiasaan pada pembelajaran jarak jauh di SDN Kotalama 1 Kota Malang.

\section{Metode}

Penelitian ini akan dilakukan dengan menggunakan metode campuran atau mixed methods. Pendekatan yang pilih yaitu pendekatan kuantitatif dan kualitatif. Penelitian campuran ini mengolah pendekatan penelitian kualitatif dan kuantitatif pada banyak fase proses penelitian tersebut (Samsu, 2017). Pemilihan metode campuran atau mixed methods guna mendapatkan hasil yang lebih baik, serta pendekatan satu dengan pendekatan lainnya akan saling mengatasi kelemahan-kelemahan satu sama lain.

Model yang digunakan pada penelitian ini yaitu explanatory design. Model ini terdiri dari dua fase, fase pertama yaitu fase pengumpulan dan analisis data kuantitatif dan fase kedua yaitu fase kualitatif yang merupakan kelanjutan dari fase kuantitatif. Tujuan dari model explanatory design yaitu data kuantitatif membantu menjelaskan atau membangun hasil penelitian kualitatif (Samsu, 2017). Penelitian ini menekankan pada pendekatan kualitatif, oleh karena itu peneliti menggunakan model explanatory design dengan varian participant selection model.

Dalam penelitian ini data kuantitatif akan diambil melalui kuesioner atau angket sikap dan perilaku yang diberikan kepada peserta didik. Sedangkan data kualitatif diambil menggunakan instrumen pedoman wawancara, pedoman observasi, dan pedoman dokumentasi. Wawancara akan dilakukan kepada guru kelas, peserta didik, dan wali murid. Observasi dilakukan melalui grup whatsapp kelas,

Angket dan kuesioner yang digunakan oleh peneliti yaitu bentuk pilihan ganda. Pilihan setiap jawaban menggunakan skala Likert. Skala Likert dapat digunakan mengukur pendapat, sikap, dan persepsi seseorang tentang fenomena sosial yang ada di masyarakat. Oleh karena itu, skala ini dipilih sesuai dengan data yang akan diukur yaitu sikap dan perilaku yang tampak setelah pelaksanaan PPK (Penguatan Pendidikan Karakter) melalui pembiasaan (Darmawan, 2014). 
Sumber data yang dipilih yaitu kelas I dan kelas VI yang mewakili kelas rendah dan kelas tinggi. Selain itu, kelas I dan VI juga merupakan kelas yang rutin melaksanakan kegiatan PPK (Penguatan Pendidikan Karakter) melalui pembiasaan dibandingkan tingkatan kelas lainnya dan tidak mengintegrasikan kegiatan PPK dengan kegiatan inti pembelajaran.

\section{Hasil dan Pembahasan}

Pelaksanaan penelitian dimulai dengan melakukan wawancara dengan guru kelas. Wawancara dengan guru kelas I dilaksanakan pada hari Senin, 15 Maret 2021 dan guru kelas VI dilaksanakan hari Jum'at 12 Maret 2021. Wawancara dilaksanakan secara langsung di SDN Kotalama 1 Kota Malang. Mengingat masih masa pandemi Covid -19 maka wawancara dilakukan dengan mematuhi protokol kesehatan yaitu memakai masker dan jaga jarak.

Hasil wawancara dengan guru kelas I dan kelas VI mengemukakan bahwa kegiatan PPK (Penguatan Pendidikan Karakter) melalui pembiasaan dibuat oleh tim kurikulum dan menjadi program mingguan. Kegiatan penguatan pendidikan karakter berbasis budaya sekolah tidak diintegrasikan dalam kegiatan inti pembelajaran di kelas. Kegiatan PPK (Penguatan Pendidikan Karakter) memiliki waktu sendiri yaitu setiap sebelum kegiatan pembelajaran dimulai baik sebelum pandemi maupun saat pandemi. Kegiatan PPK (Penguatan Pendidikan Karakter) tidak mempengaruhi nilai pengetahuan maupun nilai keterampilan, namun dapat memberikan nilai tambahan untuk nilai sikap.

Pemilihan kegiatan PPK selama pembelajaran daring (dalam jaringan) atau pembelajaran jarak jauh disesuaikan dengan kegiatan sehari-hari di rumah. Guru kelas masingmasing yang menentukan kegiatan apa saja yang akan diberikan peserta didik. Pelaksanaan kegiatan PPK (Penguatan Pendidikan Karakter) diberikan melalui grup whatsapp. Hasil pelaksanaan atau bukti pelaksanaan dapat berupa foto, video, atau voice note yang disesuaikan dengan kegiatan PPK (Penguatan Pendidikan Karakter) yang diberikan.oleh guru.

Kegiatan PPK (Penguatan Pendidikan Karakter) di kelas I dan kelas VI berbeda sesuai dengan kebijakan guru masing-masing. Di kelas I guru menyampaikan kegiatan PPK langsung di grup whatsapp dan menjadikan bukti foto kegiatan PPK sebagai bukti kehadiran peserta didik juga. Guru kelas I tidak memberikan batasan waktu untuk mengumpulkan bukti kegiatan PPK. Nilai karakter yang ditekankan yaitu nilai karakter kemandirian.

Pelaksanaan PPK di kelas VI guru memberikan batasan waktu dalam mengerjakannya yaitu pukul 07.00 sampai 08.00 WIB. Selain itu, guru kelas VI selalu mengingatkan untuk selalu mengerjakan kegiatan PPK dengan jujur. Menurut keterangan guru kelas VI pernah ada peserta didik mengirimkan foto yang diambil dari internet dan mengirimkan foto lama sebagai bukti kegiatan penguatan pendidikan karakter, maka dari itu guru selalu menekankan kejujuran. Hal berbeda lainnya yaitu pengumpulan bukti pengumpulan kegiatan PPK melalui pembiasaan di kelas VI merupakan syarat untuk mendapatkan pelajaran dan tugas pada hari itu. Jika peserta didik mengirimkan kegiatan bukti foto PPK kepada guru disiang hari maka, ia juga akan mendapat pelajaran dan tugas di siang hari juga. Jadi selain kejujuran guru kelas VI juga menekankan kedisiplinan.

Kegiatan observasi kegiatan PPK melalui pembiasaan di kelas I dan kelas VI dilaksanakan secara online melalui grup whatsapp. Observasi dilaksanakan pada tanggal 17 Maret sampai 31 Maret 2021. Hasil observasi selama dua minggu yang dilaksanakan oleh 
peneliti yaitu kegiatan PPK di kelas I jauh lebih sederhana dibanding kelas VI yang lebih kompleks.

Setiap hari Senin kegiatan PPK nilai utama karakter nasionalis, kegiatan yang diberikan guru kelas I yaitu sikap hormat bendera dan melafalkan kegiatan Pancasila. Sedangkan di kelas VI kegiatan yang diberikan yaitu memeragakan berbagai kegiatan yang ada saat upacara bendera dan membuat vlog semangat sebelum ujian praktik olahraga. Hari Selasa merupakan kegiatan PPK nilai karakter kemandirian di kelas I, kegiatan yang diberikan guru yaitu mencuci baju sendiri dan merapikan tempat tidur. Berbeda dengan kelas I, hari Selasa di kelas VI merupakan jadwal kegiatan PPK nilai karakter integritas. Kegiatan PPK nilai karakter integritas yang diberikan guru di kelas VI yaitu menyiapkan sarapan sehat yang mengandung protein, karbohidrat, dan vitamin serta membuat olahan dari buah tomat. Hari Rabu di kelas I merupakan jadwal nilai karakter integritas, kegiatan yang diberikan oleh guru kelas yaitu mematuhi peraturan yang ada seperti mengenakan seragam rapi dan lengkap dan mengerjakan tugas-tugas sebagai peserta didik. Di kelas VI hari Rabu jadwal kegiatan PPK nilai karakter kemandirian, kegiatan yang diberikan guru yaitu menyiapkan seragam sekolah sendiri dan membantu pekerjaan di rumah. Hari Kamis jadwal PPK nilai karakter gotong royong. Kegiatan yang diberikan di kelas I yaitu merawat tanaman asuh dan membuat olahan dari tomat bersama anggota keluarga. Di kelas VI guru memberikan kegiatan merawat tanaman asuh memilah sampah. Hari Jum'at jadwal kegiatan PPK nilai karakter religius. Di kelas I guru memberikan kegiatan sungkem kepada anggota keluarga yang lebih tua di rumah, melaksanakan sholat dhuha, dan membaca juz amma/iqro/Al-Qur'an. Di kelas VI kegiatan PPK yang diberikan yaitu melaksanakan sholat dhuha dan membaca surat al-kahfi ayat 1-10.

Semua bukti kegiatan PPK berupa foto, video, dan pesan suara dikirim melalui whatsapp langsung ke guru. Jika dilihat dari foto yang dikirimkan oleh peserta didik kelas I, makas terlihat masih banyak peserta didik yang tidak mengerjakan kegiatan PPK menggunakan seragam lengkap. Selain itu, di kelas I juga tidak ada batasan waktu mengerjakan kegiatan PPK. Sehingga masih ada peserta didik yang mengumpulkan kegiatan PPK di sore hari atau malam, alasannya karena orang tua bekerja dan tidak bisa mendampingi kegiatan pembelajaran di pagi hari. Guru kelas I tidak mempermasalahkan hal tersebut asalkan wali murid tetap mendampingi dan membimbing anaknya untuk mengerjakan berbagai kegiatan yang diberikan oleh guru.

Peserta didik kelas VI mayoritas sudah bisa diberi tanggung jawab untuk menggunakan handphone sendiri. Oleh karena itu, guru kelas VI memberikan batasan waktu untuk mengumpulkan kegiatan PPK. Batasan waktu ini untuk melatih kedisiplinan peserta didik. Selain itu, peranan kegiatan PPK bukan hanya sebagai syarat daftar hadir atau nilai sikap saja. Namun, juga sebagai syarat peserta didik mendapatkan tugas-tugas yang harus dikerjakan hari itu. Semakin terlambat mengerjakan PPK, maka semakin terlambat pula mendapatkan tugastugas dari guru. Tidak jarang guru memberikan teguran langsung di grup whatsapp terhadap anak-anak yang tidak segera mengerjakan kegiatan PPK.

Pengisian kuesioner atau angket sikap dan perilaku peserta didik kelas I dilaksanakan melalui google form pada hari Senin, tanggal 5 April 2021. Kuesioner atau angket sikap dan peserta didik terdapat 14 pertanyaan mengenai kebiasaan-kebiasaan mengenai kebiasaan kegiatan PPK (Penguatan Pendidikan Karakter) melalui pembiasaan pada pembelajaran jarak 
jauh. Skor maksimal setiap pertanyaan yaitu 4 dan skor minimalnya yaitu 1. Skor maksimal keseluruhan yaitu 56 dan skor minimal yaitu 14. Berikut hasil pengisian 24 peserta didik.

Tabel 1. Tabel Distribusi Frekuensi Skor Angket Kelas I

\begin{tabular}{cc}
\hline Nilai & Frekuensi \\
\hline $27-35$ & 4 \\
$36-44$ & 9 \\
$45-53$ & 12 \\
\hline
\end{tabular}

Dalam tabel 1 di atas menunjukkan tingkatan skor dibagi menjadi tiga kelas. Kelas pertama dengan rentangan skor peserta didik 27-35 terdapat 4 anak. Kelas kedua dengan rentang skor 36-44 terdapat 9 anak. Kelas ketiga rentang skor 43-53 ada 12 anak. Dari data diatas akan diambil perwakilan anak setiap kelas untuk diwawancara oleh peneliti. Tidak lupa wali murid dari peserta didik yang menjadi partisipan juga diwawancarai mengenai sikap dan perilaku anak di rumah selama kegiatan PPK (Penguatan Pendidikan Karakter) melalui pembiasaan selama pembelajaran jarak jauh.

Peserta didik kelas VI mengisi angket pada hari Kamis, 8 April 2021 melalui google form yang dikirim guru melalui grup whatsapp. Pengisian angket untuk kelas VI dilaksanakan setelah peserta didik melaksanakan ujian, jadi tidak mengganggu waktu ujian peserta didik. Skor maksimal pada angket yaitu 56 dan skor minimal 14. Berikut tabel skor hasil pengisian angket atau kuesioner sikap dan perilaku peserta didik.

Tabel 2. Tabel Distribusi Frekuensi Skor Angket Kelas VI

\begin{tabular}{cc}
\hline Nilai & Frekuensi \\
\hline $39-44$ & 5 \\
$45-50$ & 9 \\
$51-56$ & 5 \\
\hline
\end{tabular}

Tabel 2 menunjukkan skor hasil pengisian angket sikap dan perilaku peserta didik kelas VI yang dibagi menjadi 3 kelas dalam tabel distribusi frekuensi. Kelas pertama berisi 5 anak dengan rentang nilai 39 sampai 44. Kelas kedua berisi 9 anak dengan rentang nilai 45 sampai 50. Kelas ketiga berisi 5 anak dengan rentang nilai 51 sampai 56 . Nantinya setiap kelas akan diambil perwakilan peserta didik beserta wali murid untuk diwawancarai.

Setelah mengetahui skor masing-masing peserta didik, maka peneliti melakukan diskusi dengan guru kelas melalui whatsapp pada tanggal 10 April 2021 untuk menentukan beberapa partisipan yang akan diwawancarai. Peneliti melakukan persiapan dengan membuat janji dengan perantara guru kelas. Di kelas I dan kelas VI sama-sama diambil 6 orang peserta didik beserta 6 wali muridnya. Wawancara dilaksanakan di SDN Kotalama 1 Kota Malang dengan mematuhi protokol kesehatan dengan memakai masker dan jaga jarak.

Wawancara dengan peserta didik dan wali murid kelas I dilaksanakan hari Senin, 19 April 2021. Hasil wawancara dengan peserta didik yaitu peserta didik selalu mengerjakan kegiatan PPK yang diperintah oleh gurunya. Peserta didik juga menyukai kegiatan PPK yang berhubungan dengan air seperti mencuci baju menyiram tanaman. Hal ini wajar karena usia peserta didik kelas I adalah usia anak yang masih suka bermain. Ada juga beberapa kegiatan 
yang kurang disukai peserta didik yaitu kegiatan menyapu rumah, karena menurut mereka sulit dilakukan dan harus berkali-kali agar bersih. Menurut keterangan peserta didik, apabila peserta didik lupa atau tidak mengerjakan kegiatan PPK maka orang tua akan memarahi dan guru kelas akan mengingatkan untuk mengumpulkan kegiatan PPK.

Wawancara dengan orang tua peserta didik kelas I dilaksanakan di SDN Kotalama 1 Kota Malang pada hari Senin, tanggal 19 April 2021. Menurut keterangan wali murid, dengan adanya kegiatan PPK membuat anak menjadi terbiasa dengan pekerjaan sehari-hari yang ada di rumah. Nilai karakter yang terbangun dari pelaksanaan kegiatan PPK melalui pembiasaan yaitu nilai karakter kemandirian. Menurut wali murid kelas I peserta didik tampak pada saat melaksanakan pekerjaan rumah seperti menyapu, menyiapkan keperluan sekolah, dan mengerjakan tugas-tugas sekolah. Namu, dalam beberapa kegiatan PPK masih perlu bantuan orang tua seperti mengolah buah tomat yang memerlukan peralatan benda tajam seperti pisau dan alat berbahaya seperti kompor atau blender. Sedangkan karakter yang masih perlu diasah yaitu nilai karakter religius yang dapat dilihat dari sulitnya peserta didik mengerjakan sholat lima waktu. Selain itu, peserta didik kelas I kadang masih perlu dipaksa untuk mengerjakan kegiatan PPK yang diberikan oleh guru kelas.

Pelaksanaan wawancara dengan guru peserta didik kelas VI dilaksanakan di SDN Kotalama 1 Kota Malang, hari Jum'at, 12 Maret 2021. Menurut peserta didik kegiatan PPK selalu diberikan pagi hari oleh guru kelas. Kegiatan PPK yang mereka sukai yaitu kegiatan merawat lingkungan seperti menyiram tanaman dan membersihkan rumah. Menurut mereka kegiatan PPK tersebut cepat dan mudah dikerjakan, sehingga dapat segera dikumpulkan dan dapat mengerjakan tugas-tugas yang diberikan guru. Adapun kegiatan PPK yang tidak disukai yaitu kegiatan menyiapkan sarapan sehat atau mengolah bahan makanan. Alasannya karena terkadang ibu peserta didik tidak memasak atau tidak ada bahan untuk diolah di rumah, jadi harus membeli dan menyiapkan berbagai bahan serta peralatan yang membutuhkan waktu lama.

Hasil wawancara dengan orang tua peserta didik kelas VI yaitu sikap dan perilaku peserta didik di rumah yang tampak yaitu rajin, mandiri, dan tanggung jawab dalam melaksanakan tugas-tugasnya dan membantu orang tua mengerjakan pekerjaan rumah. Sikap dan perilaku rajin peserta didik terlihat saat mengerjakan berbagai tugas yang diberikan guru. Kemandirian peserta didik nampak pada saat pelaksanaan kegiatan PPK melalui pembiasaan, tanpa didampingi orang tua peserta didik mampu mengerjakan kegiatan PPK yang diberikan oleh guru. Orang tua peserta didik tidak dapat mendampingi peserta didik karena harus bekerja. Tanggung jawab peserta didik kelas VI dilihat dari sikap dan perilaku peserta didik saat melaksanakan kegiatan PPK peserta didik terlihat sungguh-sungguh. Nilai karakter yang masih belum nampak yaitu karakter religius, dimana peserta didik masih belum bisa menunjukkan sikap dan perilaku disiplin mengerjakan sholat lima waktu serta masih perlu diperintah dalam menjalankannya.

Kegiatan PPK melalui pembiasaan di SDN Kotalama 1 Kota Malang selalu dilaksanakan secara rutin setiap pagi sebelum kegiatan pembelajaran dimulai. Jadwal PPK telah disusun oleh tim kurikulum dan guru kelaslah yang menyiapkan dan menentukan kegiatan apa saja yang ada. Kegiatan spontan dalam PPK yaitu disesuaikan dengan kebutuhan, misalnya menanam tanaman asuh tumbuhan tomat merupakan salah satu program adiwiyata dengan 
mewujudkan sekolah seribu tomat. Sehingga peserta didik diminta untuk menanam tanaman tomat.

PPK atau Penguatan Pendidikan Karakter merupakan salah satu program yang disusun oleh kemendikbud guna meningkatkan karakter peserta didik dalam kurikulum 2013. Pendidikan Karakter merupakan upaya menjadikan peserta didik berkarakter baik, peduli, rasa sosial yang tinggi, keadilan kebajikan, dan tanggung jawab agar dapat dapat mengambil keputusan sendiri dan berkontribusi bagi orang lain dan lingkungan (Akbar, 2017; Barnawi \& Arifin, 2012).

Penguatan Pendidikan Karakter merupakan program gerakan pendidikan di bawah tanggung jawab satuan pendidikan untuk memperkuat karakter peserta didik melalui harmonisasi oleh hati, olah rasa, olah pikir, olah raga dengan melibatkan dan bekerjasama antar satuan pendidikan, keluarga dan masyarakat sebagai bagian dari Gerakan Nasional Revolusi Mental (GNRM) (Permendikbud No. 20 Tahun 2018).

Program pembiasaan dalam konteks kegiatan PPK merupakan perwujudan dari pendidikan karakter di SDN Kotalama 1 Kota Malang. PPK (Penguatan Pendidikan Karakter) melalui pembiasaan merupakan PPK berbasis budaya sekolah. Kegiatan sudah dijadwalkan setiap minggunya dan guru kelas yang memilih dan menentukan kegiatan atau aktivitas kegiatan PPK yang akan diberikan kepada peserta didik.

Berdasarkan hasil wawancara, observasi, dan dokumentasi menunjukkan bahwa pelaksanaan kegiatan PPK di kelas I dan kelas VI SDN Kotalama 1 Kota Malang telah berjalan sesuai jadwal yang telah ditentukan oleh tim kurikulum. Guru kelas memberikan kegiatan PPK melalui pembiasaan berbeda setiap harinya disesuaikan dengan nilai karakter. Namun, menurut hasil wawancara dengan beberapa wali murid di kelas I karakter yang nampak dalam diri peserta didik yaitu kemandirian yang terlihat saat menyiapkan peralatan sekolah sendiri dan menggunakan seragam sekolah. Sedangkan menurut wali murid kelas VI, karakter yang nampak dalam diri peserta didik yaitu karakter mandiri, rajin, dan tanggung jawab.

Peranan penguatan pendidikan karakter melalui pembiasaan di SDN Kotalama 1 Kota Malang selama pembelajaran jarak jauh menurut guru kelas I yaitu sebagai pengenalan kegiatan sehari-hari di rumah dan dapat belajar mengerjakannya sesuai dengan kemampuannya sehingga menjadi kebiasaan. Hal ini juga dibenarkan oleh wali murid SDN Kotalama 1 Kota Malang yang mengemukakan bahwa kegiatan PPK dapat membiasakan peserta didik membantu pekerjaan yang ada di rumah. Kegiatan PPK melalui pembiasaan di kelas VI memiliki peranan yang tidak biasa yaitu sebagai syarat untuk mendapatkan tugastugas hari itu. Hal tersebut dilakukan guru untuk meningkatkan sikap dan perilaku tanggung jawab dan kedisiplinan peserta didik.

Jadi peranan kegiatan PPK melalui pembiasaan yang dilaksanakan selama pembelajaran jarak jauh di SDN Kotalama 1 Kota Malang bertujuan membuat mengenalkan peserta didik berbagai kegiatan atau aktivitas sehari-hari di rumah, melatih dan membiasakan peserta didik melakukan pekerjaan rumah, serta membangun berbagai nilai karakter antara lain religius, nasionalis, mandiri, gotong-royong, dan integritas yang diwujudkan dalam berbagai aktivitas sehari-hari. 


\section{Simpulan}

Berdasarkan hasil penelitian yang telah dilaksanakan peneliti, secara umum implementasi kegiatan PPK (Penguatan Pendidikan Karakter) melalui pembiasaan pada pembelajaran jarak jauh di SDN Kotalama 1 Kota Malang telah berjalan sesuai dengan jadwal dan dilaksanakan secara rutin. Secara rutin implementasi kegiatan PPK melalui pembiasaan di SDN Kotalama 1 Kota Malang selama pembelajaran jauh diberikan guru melalui whatsapp. Nilai utama karakter PPK diberikan berbeda setiap harinya, kegiatan yang diberikan yaitu kegiatan sehari-hari yang ada di rumah. Tentunya kegiatan yang diberikan guru ke peserta didiknya disesuaikan dengan tingkatan dan karakteristik peserta didik.

\section{Daftar Rujukan}

Affan, M. Husin, \& Maksum, Hafidh. (2016). Mambangun Kembali Sikap Nasionalisme Bangsa Indonesia dalam Menangkal Budaya Asing di Era Globalisasi. Jurnal Pesona Dasar: Pendidikan Guru Sekolah Dasar Universitas Syiah Kuala. 3(4), 65-72.

Akbar, S. (2011). Revitalisasi Pendidikan Karakter di Sekolah Dasar. Pidato Pengukuhan Guru Besar Dalam Bidang Ilmu Pendidikan/Pendidikan Dasar. Malang: Universitas Negeri Malang.

Akbar, S. (2016). Best Practices Pendidikan Karakter. Seminar Nasional Jurusan KSDP Prodi S1 PGSD. Malang: Universitas Negeri Malang.

Akbar, S. (2016). Internalisasi Nilai-nilai Kebaikan dalam pembelajaran di Kelas SD. Seminar Nasional Jurusan KSDP Prodi S1 PGSD. Malang: Universitas Negeri Malang.

Akbar, S. (2016). Model Pembelajaran Nilai dan Karakter Berbasis Nilai-nilai Kehidupan di Sekolah Dasar. Seminar Nasional Jurusan KSDP Prodi S1 PGSD. Malang: Universitas Negeri Malang.

Akbar, S. (2017). Instrumen Perangkat Pembelajaran. Bandung: PT. Remaja Rosdakarya.

Barnawi \& Arifin, M. (2012). Strategi \& Kebijakan Pembelajaran Pendidikan Karakter. Jogjakarta: Ar-ruzz Media.

Fitri, A. Z. (2012). Pendidikan Karakter Berbasis Nilai dan Etika di Sekolah. Yogyakarta: Ar-ruzz Media.

Permendikbud Nomor 20 Tahun 2018 tentang Penguatan Pendidikan Karakter pada Satuan Pendidikan Formal.

Samani, M. \& Hariyanto. (2012). Konsep dan Model Pendidikan Karakter. Bandung: Remaja Rosdakarya.

Samsu. (2017). Metode Penelitian: (Teori dan Aplikasi Penelitian Kualitatif, Kuantitatif, Mixed Methods, serta Research \& Development). Jambi: Pusaka Jambi.

Tim Penulis. (2017). Pedoman Penulisan Karya Ilmiah. Malang: Universitas Negeri Malang.

Tim PPK. (2017). Konsep dan Pedoman Penguatan Pendidikan Karakter. Jakarta: Kementrian Republik Indonesia.

Undang-Undang Republik Indonesia Nomor 20 Tahun 2003 tentang Sistem Pendidikan Nasional. 